\section{Expression Profiles and Mechanisms of microRNAs in Prostate Cancer}

\section{Abstract}

MicroRNAs are small non-coding RNA molecules with a length of 20 to 25 nucleotides. As gene expression regulators, microRNAs can completely or not completely complementarily bind with mRNA to inhibit translation or degradate mRNA. Aberrant expression of microRNAs is closely related to the occurrence, development, metastasis and prognosis of prostate cancer. Some microRNAs may promote cancerization, while others are tumor suppressors. In this review, we summarized the expression profiles of microRNAs in recent years, in particular, the data obtained by large-scale high-throughput technologies. We also summed up microRNAs which had the potential to be biomarkers of prostate cancer, and the mechanisms of microRNAs in the developmental progression of prostate cancer. The review provided medical and scientific researchers with an overview of the status and role of microRNAs in prostate cancer. In short, we summarized the expression profiles of microRNAs discovered in recent years and their roles and mechanisms in the occurrence and development of prostate cancer.

Key words: Meta-MicroRNAs; Prostate cancer; Expression profile; Biomarker

Received: July 02, 2018; Accepted: JJuly 12, 2018; Published: July 20, 2018

\section{Song $\mathrm{C}^{1 *}$, Chen $\mathrm{H}^{2}$ and Chunyu $\mathrm{S}^{3}$}
1 Medical Research Center, Shaoxing People's Hospital, Shaoxing, Zhejiang province, China
2 Zhejiang Institute of Microbiology/Key Laboratory of Microorganism Technology and Bioinformatics Research of Zhejiang Province, Hangzhou, Zhejiang, China
3 The Department of Anesthesia, the Second Clinical Hospital of Harbin Medical University, Harbin, Heilongjiang province, China

\section{*Corresponding author: Chunjiao Song chunjiaosong@163.com}

Medical Research Center, Shaoxing People's Hospital, Shaoxing Hospital, Zhejiang University School of Medicine, Shaoxing, Zhejiang province, China.

Tel: 86057588228687

Citatiton: Song $\mathrm{C}$, Chen $\mathrm{H}$ and Chunyu S (2018) Expression Profiles and Mechanisms of microRNAs in Prostate Cancer. Biomark J. Vol.4 No.3:13

microRNAs (miRNAs) are small conserved endogenous noncoding RNAs with the length of 20-25 nt, which regulate target genes by complementarily binding to the 3 '-untranslated regions (UTR) of target mRNAs. It was estimated that each miRNA could regulate hundreds of target genes, and each mRNA could be bound by hundreds of different miRNAs. So, about $60 \%$ of coding genes were regulated by miRNAs encoded by $1 \%$ of human genome [4]. Nowadays, more than 4800 human mature miRNAs were reported in miRBase v22 (http://www.mirbase.org/). miRNAs may effect a wide variety of cellular processes, such as cell proliferation, differentiation, and apoptosis, etc. miRNAs may also participate in multiple cellular pathways in a variety of solid tumors by dual roles: Oncogenic miRNAs or tumor suppressor miRNAs.

The goals of this review are to summarize the expression 
profiles of microRNAs in $\mathrm{PCa}$, and to identify the predictive biomarkers which may isolate the lethal or drug-resistant patients to reduce overtreatment and to improve personalized treatment effect.

\section{The Expression Profiles Of Micrornas In Prostate Cancer}

Previously, we scanned the miRNAs expression profiles in highrisk and low-risk PCa tissue samples using the second-generation sequencing and quantitative real-time PCR (qRT-PCR) technology [5]. The obtained results were summarized in Table 1 together with other literatures' data [6,7]. Some of these miRNAs expression were controversial in different studies, while others were consistent in tissue and body fluid specimens, which were all marked in Table 1. Obviously, miRNAs with consistent results reported in all literatures could provide more valuable information. For example, miR-26a, miR-106a and miR-141 were up-regulated in PCa tissues and serum samples. In addition, the gene encoded a sort of miRNA may produce multiple mature miRNA products due to different splicing processes, and they often have the same target genes and synergistic effects. Currently, there were more than 300 miRNAs differentially expressed in PCa tissues, and 49 miRNAs detected in serum, 4 in urine samples (Table 1). These differentially expressed data were collected from different studies screening various prostate samples, such as prostate cancer (PCa), benign prostate controls, castration resistance prostate cancer (CRPC) and hormone sensitive PCa, and metastatic PCa, etc.

Following the rapid development of new high-throughput technologies, such as whole-genome analysis, deep sequencing and microarray, in particular, single-cell genome/transcriptome sequencing, researchers may get the miRNAs expression data in specific time and space from these large-scale analyses.

\section{microRNAs as biomarkers for prostate cancer}

At present, a lot of studies have focused on the correlation between specific miRNA expression level and various clinical features of $\mathrm{PCa}$, such as tumor stage, Gleason score, metastasis, biochemical recurrence and disease specific death, etc. We also conducted a meta-analysis to evaluate the application value of miRNAs as PCa biomarkers. Our results supported that miRNAs might distinguish the different states of PCa and predict the prognosis of PCa [8]. About 180 miRNAs related to the prognosis, recurrence and metastasis of PCa have been found and summarized in Table 2.

miRNAs were good biomarkers because they not only could noninvasively identify $\mathrm{PCa}$, but also were stable in a variety of samples and could be detected in a variety of methods. In Table

Table 1: The expression profile of microRNAs in prostate cancer.

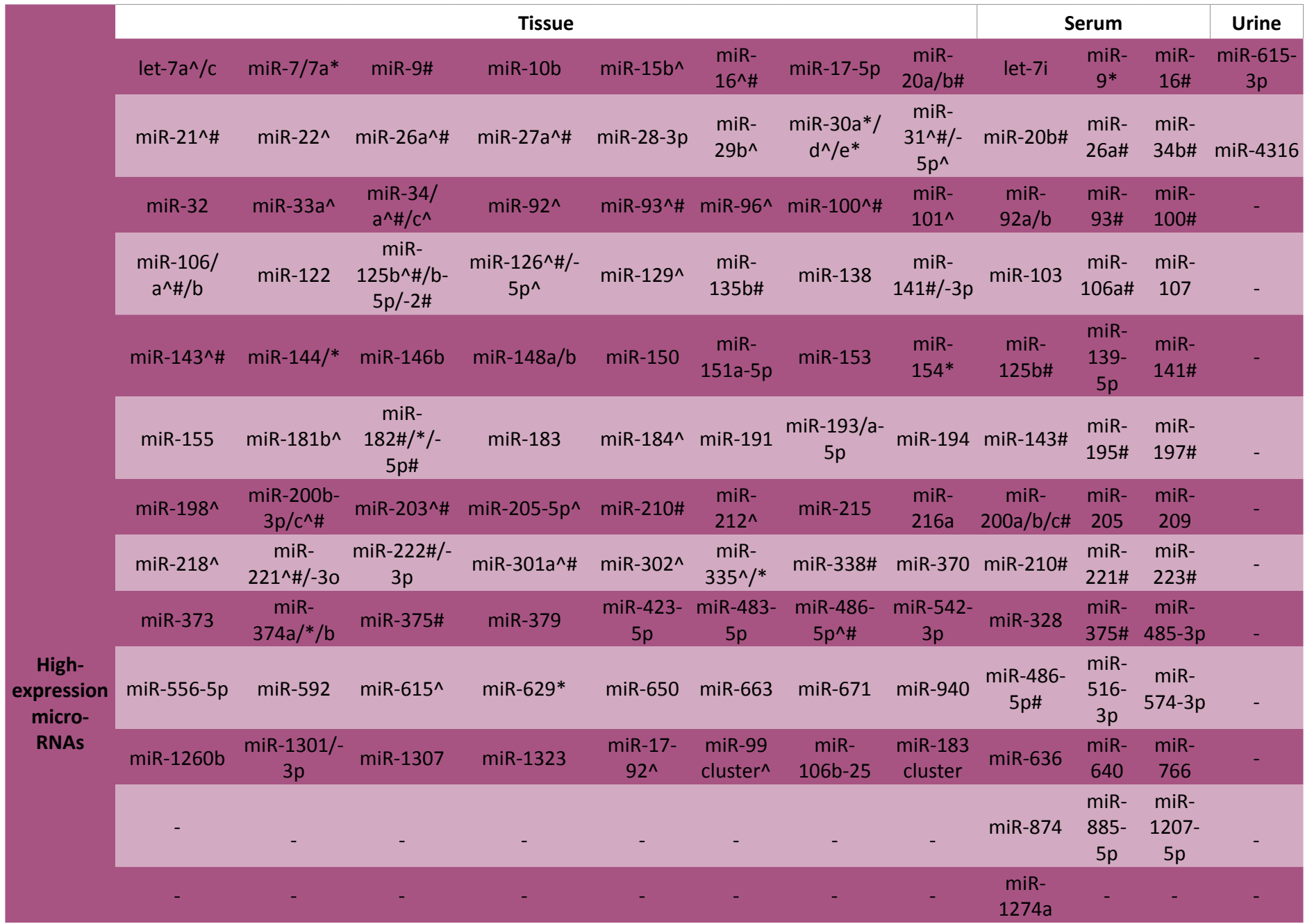




\begin{tabular}{|c|c|c|c|c|c|c|c|c|c|c|c|c|}
\hline & let-7a^/d\#/g & miR-1 & miR-7-1* & miR-8 & $\operatorname{miR}-15 b^{\wedge}$ & $\operatorname{miR}-16^{\wedge}$ & miR-17/-3p & $\begin{array}{l}\text { miR- } \\
21^{\wedge} \#\end{array}$ & $\begin{array}{c}\text { miR- } \\
15 a / 16-1\end{array}$ & $\begin{array}{l}\mathrm{miR}- \\
24 \#\end{array}$ & $\begin{array}{l}\text { miR- } \\
26 b \#\end{array}$ & miR-205\# \\
\hline & $\operatorname{miR}-22^{\wedge}$ & $\begin{array}{c}\text { miR- } \\
23 a \# / b\end{array}$ & miR-24\# & miR-25 & $\begin{array}{c}\operatorname{miR}-26 a^{\wedge} / \\
a-5 p / b \#\end{array}$ & $\begin{array}{c}\mathrm{miR}-27 / \\
\mathrm{a}^{\wedge} \#\end{array}$ & miR-28-5p & $\begin{array}{c}\text { miR-29a/ } \\
b^{\wedge} / c\end{array}$ & miR-30c & $\begin{array}{l}\text { miR- } \\
107 \#\end{array}$ & $\begin{array}{l}\text { miR- } \\
129 \#\end{array}$ & miR-214 \\
\hline & $\operatorname{miR}-30 d^{\wedge}$ & $\begin{array}{c}\operatorname{miR}-31^{\wedge} \# /- \\
5 p^{\wedge}\end{array}$ & $\operatorname{miR}-33 a^{\wedge}$ & $\begin{array}{c}\text { miR- } \\
34 a^{\wedge} \# / b \# / \\
c^{\wedge} / c-5 p\end{array}$ & $\operatorname{miR}-92^{\wedge}$ & $\operatorname{miR}-93^{\wedge}$ & $\operatorname{miR}-96^{\wedge}$ & miR-98 & miR-223\# & - & - & - \\
\hline & $\operatorname{miR}-100^{\wedge}$ & $\operatorname{miR}-101^{\wedge}$ & $\operatorname{miR}-106 a^{\wedge}$ & miR-107\# & miR-124\# & $\begin{array}{c}\text { miR-125/ } \\
a-3 p / \\
b^{\wedge} \#\end{array}$ & $\begin{array}{c}\mathrm{miR}- \\
126^{\wedge} \# /^{*} /- \\
5 p^{\wedge}\end{array}$ & $\begin{array}{l}\text { miR- } \\
128 / a\end{array}$ & - & - & - & - \\
\hline & miR-129^\# & miR-130b & miR-132 & miR-133b\# & miR-140 & $\begin{array}{l}\text { miR- } \\
143^{\wedge}\end{array}$ & $\begin{array}{c}\text { miR-145\#/- } \\
5 p \#\end{array}$ & $\begin{array}{l}\text { miR- } \\
146 a\end{array}$ & - & - & - & - \\
\hline & miR-148\# & miR-149 & $\begin{array}{c}\operatorname{miR}-151 a- \\
3 p\end{array}$ & miR-152/-3p & miR-154 & $\begin{array}{c}\text { miR- } \\
181 b^{\wedge} / \mathrm{b}- \\
1 \# / c \#\end{array}$ & $\operatorname{miR}-184^{\wedge}$ & miR-186 & - & - & - & - \\
\hline & miR-187 & miR-190a & miR-192 & miR-193b & miR-195 & $\begin{array}{l}\text { miR- } \\
196 b\end{array}$ & $\operatorname{miR}-198^{\wedge}$ & $\begin{array}{l}\text { miR-199 } \\
a / a-3 p / b\end{array}$ & - & - & - & - \\
\hline & $\begin{array}{l}\mathrm{miR}-200 / \\
b / b^{*} / c^{\wedge} \#\end{array}$ & miR-203^\# & miR-204 & $\begin{array}{c}\text { miR-205\#/- } \\
5 p^{\wedge}\end{array}$ & miR-206 & $\begin{array}{l}\text { miR- } \\
212^{\wedge}\end{array}$ & $\operatorname{miR}-218^{\wedge}$ & $\begin{array}{c}\text { miR-219- } \\
5 p\end{array}$ & - & - & - & - \\
\hline $\begin{array}{l}\text { Low- } \\
\text { expression }\end{array}$ & $\operatorname{miR}-221^{\wedge} \#$ & $\operatorname{miR}-223^{\wedge}$ & miR-224 & miR-296-5p & $\begin{array}{c}\mathrm{miR}-301 / \\
a^{\wedge} \# / b\end{array}$ & $\begin{array}{c}\text { miR- } \\
320^{\wedge} / a \#\end{array}$ & $\begin{array}{c}\text { miR-331- } \\
3 p\end{array}$ & $\begin{array}{l}\mathrm{miR}- \\
335^{\wedge}\end{array}$ & - & - & - & - \\
\hline $\begin{array}{l}\text { micro- } \\
\text { RNAs }\end{array}$ & miR-339-5p & miR-376c & miR-378 & miR-432 & $\begin{array}{l}\text { miR- } \\
\text { 449a\# }\end{array}$ & $\begin{array}{c}\text { miR- } \\
452 /-5 p\end{array}$ & $\begin{array}{c}\text { miR-486- } \\
5 p^{\wedge} \#\end{array}$ & miR-490 & - & - & - & - \\
\hline & miR-491-5p\# & $\begin{array}{c}\text { miR-493- } \\
3 p / 5 p\end{array}$ & miR-494 & miR-503 & $\begin{array}{l}\text { miR-511- } \\
\quad 3 p\end{array}$ & $\begin{array}{c}\text { miR- } \\
519 d /-3 p\end{array}$ & miR-520h & $\begin{array}{c}\text { miR-532- } \\
\quad 3 p\end{array}$ & - & - & - & - \\
\hline & miR-542-5p & miR-564 & miR-605 & $\operatorname{miR}-615^{\wedge}$ & $\begin{array}{l}\text { miR-628- } \\
5 p\end{array}$ & miR-631 & $\begin{array}{l}\text { miR-875- } \\
5 p\end{array}$ & $\begin{array}{l}\text { miR- } \\
1256\end{array}$ & - & - & - & - \\
\hline & $\begin{array}{c}\text { miR-1207- } \\
\text { 3p\# }\end{array}$ & miR-1271 & miR-1296 & miR-3619-5p & $\begin{array}{c}\text { miR-1- } \\
133 a\end{array}$ & $\begin{array}{c}\mathrm{miR}-17- \\
92 \mathrm{a}^{\wedge}\end{array}$ & $\begin{array}{l}\text { miR-99 } \\
\text { cluster^}^{\wedge}\end{array}$ & $\begin{array}{l}\text { miR-200 } \\
\text { cluster }\end{array}$ & - & - & - & - \\
\hline $\begin{array}{l}\text { miRNA } \\
\text { in CRPC }\end{array}$ & let-7f & miR-21\# & miR-27h & miR-100/-5p & miR-122a & $\begin{array}{c}\text { miR- } \\
125 b^{\wedge} \#\end{array}$ & miR-133b\# & $\begin{array}{c}\text { miR- } \\
141^{\wedge} \#\end{array}$ & miR-141\# & $\begin{array}{l}\text { miR- } \\
\text { 375\# }\end{array}$ & $\begin{array}{l}\mathrm{miR}- \\
378^{*}\end{array}$ & - \\
\hline $\begin{array}{l}\text { miRNA in } \\
\text { ADPC High- } \\
\text { expression }\end{array}$ & miR-145\# & miR-154* & miR-181a & $\operatorname{miR}-184^{\wedge}$ & miR-195 & $\begin{array}{c}\text { miR- } \\
196 a / b- \\
3 p\end{array}$ & miR-221\# & $\begin{array}{c}\text { miR- } \\
222^{\wedge} \#\end{array}$ & - & - & - & - \\
\hline $\begin{array}{c}\text { in } \\
\text { metastatic } \\
\text { Pca }\end{array}$ & $\operatorname{miR}-361 /-5 p$ & miR-383 & $\operatorname{miR}-424$ & $\operatorname{miR}-487$ & miR-488\# & $\begin{array}{l}\text { miR-582- } \\
5 p\end{array}$ & miR-616 & $\begin{array}{c}\text { miR- } \\
23 b-24\end{array}$ & - & - & - & - \\
\hline & let-7/c\# & miR-17-5p & miR-19b & miR-20a & miR-29b & miR-34 & miR-92a & $\begin{array}{c}\text { miR- } \\
125 b^{\wedge} \#\end{array}$ & $\begin{array}{c}\text { miR-409- } \\
3 p\end{array}$ & - & - & - \\
\hline & miR-128b & miR-141^\# & $\begin{array}{l}\text { miR-145- } \\
\text { 3p\#/-5p\# }\end{array}$ & $\mathrm{miR}-146 \mathrm{a} / \mathrm{b}$ & miR-148a & $\begin{array}{l}\mathrm{miR}- \\
184^{\wedge}\end{array}$ & miR-198 & $\begin{array}{c}\mathrm{miR}-200 \\
\mathrm{~b}-3 \mathrm{p} / \mathrm{c}\end{array}$ & - & - & - & - \\
\hline & miR-205 & miR-222^\# & $\begin{array}{c}\text { miR-331- } \\
3 p\end{array}$ & miR-663 & miR-3654 & $\underset{4638-5 p}{\text { miR- }}$ & $\begin{array}{c}\text { miR-4735- } \\
3 p\end{array}$ & $\begin{array}{c}\text { miR- } \\
106 b-25\end{array}$ & - & - & - & - \\
\hline $\begin{array}{l}\text { High- } \\
\text { expression }\end{array}$ & let-7c\# & miR-10 & miR-24 & miR-26 & miR-27 & $\operatorname{miR}-30 c$ & $\operatorname{miR}-100^{\wedge}$ & $\begin{array}{l}\text { miR- } \\
125 b \#\end{array}$ & $\operatorname{miR}-451$ & - & - & - \\
\hline $\begin{array}{c}\text { in } \\
\text { metastatic } \\
\text { Pca }\end{array}$ & miR-126\# & $\begin{array}{l}\text { miR-129- } \\
\quad 3 p\end{array}$ & miR-141\# & miR-152 & $\begin{array}{c}\text { miR-181/ } \\
a^{\wedge} / b- \\
1 \# / c \#\end{array}$ & $\begin{array}{l}\text { miR-210- } \\
\text { 3p\# }\end{array}$ & miR-218 & $\begin{array}{l}\text { miR- } \\
221 \#\end{array}$ & - & - & - & - \\
\hline & miR-222\# & miR-224 & miR-338\# & $\begin{array}{c}\text { miR-409-3p/- } \\
5 p\end{array}$ & miR-543 & $\begin{array}{l}\text { miR-590- } \\
5 p\end{array}$ & $\begin{array}{c}\text { miR-1247- } \\
5 p\end{array}$ & $\begin{array}{c}\text { miR- } \\
106 b-25\end{array}$ & - & - & - & - \\
\hline
\end{tabular}




\begin{tabular}{|c|c|c|c|c|c|c|c|c|c|c|c|c|}
\hline \multirow{5}{*}{$\begin{array}{l}\text { Low- } \\
\text { expression } \\
\text { in } \\
\text { metastatic } \\
\text { PCa }\end{array}$} & miR-1 & miR-21 & miR-23b & $\operatorname{miR}-27 b$ & miR-29b & $\begin{array}{l}\text { miR-30b- } \\
3 p / d-5 p\end{array}$ & miR-33a & $\begin{array}{l}\text { miR- } \\
34 \mathrm{~b} \#\end{array}$ & - & - & - & - \\
\hline & miR-96 & $\operatorname{miR}-100^{\wedge}$ & miR-133a & $\begin{array}{c}\text { miR-135a- } \\
1 / b \#\end{array}$ & $\begin{array}{c}\text { miR- } \\
141 \# /-3 p\end{array}$ & miR-143 & miR-145\# & $\begin{array}{l}\text { miR- } \\
146 a\end{array}$ & - & - & - & - \\
\hline & miR-154 & $\begin{array}{c}\mathrm{miR}- \\
181 \mathrm{a} / \mathrm{b}\end{array}$ & miR-182\# & miR-183 & $\begin{array}{c}\text { miR-188- } \\
5 p\end{array}$ & $\begin{array}{l}\text { miR- } \\
193 a\end{array}$ & $\begin{array}{c}\mathrm{miR}-200 / \mathrm{a} / \\
\mathrm{b} / \mathrm{c} \#\end{array}$ & $\begin{array}{l}\text { miR- } \\
\text { 203\# }\end{array}$ & - & - & - & - \\
\hline & miR-205 & miR-373 & miR-429 & miR-449a\# & $\begin{array}{c}\text { miR-486- } \\
5 p \#\end{array}$ & $\begin{array}{c}\text { miR-508- } \\
5 p\end{array}$ & miR-520c & $\begin{array}{l}\text { miR- } \\
573 \#\end{array}$ & - & - & - & - \\
\hline & miR-618 & miR-675 & - & - & - & - & - & - & - & - & - & - \\
\hline
\end{tabular}

Note: ADPC-Androgen-dependent prostate cancer; CRPC-castration resistant prostate cancer ; PCa-prostate cancer; ${ }^{\wedge}$-microRNAs inconsistently reported in different papers; \#-microRNAs detected in both prostate cancer tissues and serum/urine samples or microRNAs with mechanism studies were conducted.

2, we found that the miRNA biomarkers in serum, especially urine samples, were still insufficient, which would be the direction of scientific researchers' efforts. In addition, a large number of studies have begun to focus on multiple miRNAs combined with other indicators to jointly predict PCa and its prognosis, such as PSA (prostate specific antigen), PCA3 (prostate cancer antigen 3) and fusion gene TMPRSS2-ERG, etc. In Table 2, the miQ index was invented by Larne et al. [9]. It could differentiate PCa accurately and had the potential to predict prognosis [9]. This was also an effective strategy to avoid high heterogeneity of PCa.

\section{THE Mechanism Of Micrornas In Prostate Cancer Progression}

Most miRNAs are transcribed by RNA polymerase II, processed by Drosha and Dicer, and transported out of the nucleus by Exportin- 5 during this period. Finally, the mature miRNAs become the 18-25 nt duplexes, assembled into the RNA-induced silencing complex (RISC). Moreover, most mature miRNAs combine with the $3^{\prime}$-UTR of the target messenger RNA, a few mature miRNAs bind to $5^{\prime}$ UTR. Some studies have shown that miRNAs can also combined to the coding regions or the specific sequence promoter of target genes [10-12].

\section{The Mechanism Of Abnormal Expression Of Mirnas In Prostate Cancer}

miRNAs have dual functions: oncogenic miRNAs can activate carcinogenesis, tumor suppressor miRNAs can inhibit tumor progression. Among them, carcinogenic miRNAs are usually highly expressed in $\mathrm{PCa}$, while tumor suppressor miRNAs are down-regulated. In high-risk PCa and CRPC (Castration Resistant Prostate Cancer), the expression of Dicer and Drosha/DGCR8 was significantly increased, which contributed to the processing and up-regulated the expression of oncogenic miRNAs $[13,14]$. On the contrary, Drosha or Dicer expression decreased would attenuate mature miRNA biogenesis $[15,16]$. Myc could inhibit the binding of miR-26a/b to RNA polymerase II, thus affecting its transcription [17].

On the other hand, the genes that encoded tumor suppressor miRNAs were deleted in $60 \%$ of PCa samples $[18,19]$. Mutations or polymorphisms of tumor suppressor miRNAs might also lead to down-regulation of their expression, and increase the susceptibility to PCa $[20,21]$. In addition, methylation of the promoters of tumor suppressor miRNAs also reduced their expression, increasing the risk of PCa [22-24].

In addition to the above mentioned mechanisms leading to abnormal miRNAs expression, it was worth mentioning that the absence or variation of target genes was also one of the important reasons for the development of PCa. Feng et al. found that the $\mathrm{C} / \mathrm{T}$ polymorphism of BMPRIB located in the 3'-UTR of this gene where was the binding site of miR-125b, could cause miR-125b not to bind to this region and lose its regulatory role, increasing the risk of cancer $[25,26]$.

\section{Micrornas Associated With Androgen Receptor Signaling Pathways}

Early clinical PCa was mostly androgen-sensitive, but some of these cases would progress to incurable CRPC or metastatic PCa after initial treatment or ADT. These suggested that androgen receptor (AR) played an important role in the evolution of PCa. AR is a nuclear hormone receptor as a transcription factor to regulate the expression of a large number of downstream target genes. Previously, we had reviewed miRNAs related to AR signaling pathways [27]. In the review, we had not only summarized many miRNAs regulated by $A R$, but also gathered the miRNAs that directly and indirectly regulated AR [27].

Ostling et al. detected 71 miRNAs in a large sample study that affected AR expression levels by binding to AR 3'-UTR region of 6 $\mathrm{Kb}$ length [28]. miR-135b, miR-147, miR-34a, miR-644, miR-297, miR-298, miR-299-3p, miR-371-3p, miR-421, miR-449/b, miR491-5p and miR-876-3p reduced AR mRNA levels, and miR-488 decreased AR protein levels, while miR-644 increased AR mRNA levels [28]. In addition, other research groups found that miR-34b [18], miR-124 [29], miR-145 [30], miRNA-221/222 [14], miR-301a [31], miR-320a [32] and miR-449a [33] could directly regulate $A R$ expression and AR signaling pathway activity. miR-31 bound to the coding region of $A R$ gene, which was usually mutated in PCa [34]. miR-1207-3p indirectly regulated $A R$ activity through direct target molecule FNDC1 to form a new miR-1207-3p/FNDC1/FN1/ $A R$ pathway in PCa [35]. miR-185 could indirectly attenuate $A R$ function by inhibiting BRD8 ISO2 [36]. Furthermore, miR-2909 and $A R$ regulated each other to structure a positive feedback loop [37], while a negative feedback loop was formed between miR124 and AR [38].

In addition to the above mentioned miRNAs that regulated $A R$, there were many miRNAs that were regulated by AR. Androgen could stimulate a variety of miRNAs expression, such as: miR-21 
Table 2: MicroRNAs as biomarkers in prostate cancer.

\begin{tabular}{|c|c|c|c|c|c|c|c|c|c|c|c|c|}
\hline \multirow{6}{*}{ Items } & \multicolumn{8}{|c|}{ Tissue } & \multicolumn{3}{|c|}{ Serum } & \multirow{2}{*}{$\begin{array}{l}\text { Urine } \\
\text { miR- } \\
\text { 145\# }\end{array}$} \\
\hline & let-7a/b & $\begin{array}{c}\mathrm{miR}- \\
16 \#\end{array}$ & miR-21\# & miR-23b & miR-96 & $\begin{array}{l}\text { miR- } \\
106 a\end{array}$ & $\begin{array}{l}\text { miR- } \\
141 \#\end{array}$ & miR-149 & let-7c\# & $\begin{array}{c}\text { miR- } \\
15 a / 16-1 \#\end{array}$ & $\begin{array}{c}\text { miR- } \\
19 / b-3 p\end{array}$ & \\
\hline & miR-150 & $\begin{array}{l}\text { miR- } \\
182 \#\end{array}$ & miR-185\# & miR-187 & $\begin{array}{c}\text { miRNA- } \\
\text { 200c\# }\end{array}$ & $\begin{array}{l}\text { miR- } \\
205 \#\end{array}$ & $\begin{array}{l}\text { miR- } \\
221 \#\end{array}$ & miR-222\# & miR-21\# & miR-30c & $\begin{array}{l}\text { miR- } \\
34 b \#\end{array}$ & $\begin{array}{l}\text { miR- } \\
193 b\end{array}$ \\
\hline & miR-224 & $\begin{array}{l}\text { miR- } \\
452\end{array}$ & miR-551 & miR-663 & $\begin{array}{l}\text { miR- } \\
1274\end{array}$ & $\begin{array}{l}\text { miR- } \\
\text { 2909\# }\end{array}$ & $\mathrm{miQ}$ & $\begin{array}{l}\text { miR- } \\
130 b- \\
301 b\end{array}$ & miR-129 & $\begin{array}{c}\text { miR-139- } \\
5 p\end{array}$ & $\begin{array}{l}\text { miR- } \\
141 \#\end{array}$ & $\begin{array}{l}\text { miR- } \\
\text { 205\# }\end{array}$ \\
\hline & - & - & - & - & - & - & - & - & $\begin{array}{c}\text { miR-151- } \\
3 p\end{array}$ & $\begin{array}{c}\text { miR-200a/ } \\
\text { b/c\# }\end{array}$ & miR-203 & $\begin{array}{l}\text { miR- } \\
214 \#\end{array}$ \\
\hline & - & - & - & - & - & - & - & - & miR-205\# & miR-214\# & $\begin{array}{l}\text { miR- } \\
297 \#\end{array}$ & - \\
\hline \multirow[t]{5}{*}{ Diagnosis } & - & - & - & - & - & - & - & - & $\begin{array}{c}\text { miR- } \\
\text { 320a\#/ } \\
\text { b/c }\end{array}$ & miR-345 & $\begin{array}{l}\text { miR- } \\
375 \#\end{array}$ & - \\
\hline & - & - & - & - & - & - & - & - & $\begin{array}{c}\text { miR- } \\
519 c-5 p\end{array}$ & $\begin{array}{c}\text { miR- } \\
\text { 2909\# }\end{array}$ & - & - \\
\hline & $\begin{array}{c}\text { let-7a- } \\
1 / a / f\end{array}$ & miR-9\# & miR-15b & miR-16 & miR-21\# & miR-24 & miR-26a & miR-29a* & miR-19a\# & miR-20a & miR-21\# & - \\
\hline & miR-30d & $\begin{array}{c}\mathrm{miR}- \\
31 \#\end{array}$ & miR-33 & miR-34a* & miR-93 & miR-96 & $\begin{array}{l}\text { miR- } \\
106 a\end{array}$ & $\begin{array}{l}\text { miR- } \\
125 b \#\end{array}$ & miR-141\# & miR-200b & $\begin{array}{l}\text { miR- } \\
221 \#\end{array}$ & - \\
\hline & miR-126* & $\begin{array}{c}\text { miR- } \\
132\end{array}$ & miR-143 & miR-145\# & miR-152 & $\begin{array}{l}\text { miR- } \\
182 \#\end{array}$ & miR-195 & miR-205 & miR-375\# & miR-451\# & - & - \\
\hline \multirow{3}{*}{$\begin{array}{l}\text { Gleason } \\
\text { score }\end{array}$} & miR-221\# & $\begin{array}{l}\text { miR- } \\
\text { 222\# }\end{array}$ & miR-296 & $\begin{array}{c}\text { miR-331- } \\
3 p\end{array}$ & $\begin{array}{c}\text { miR- } \\
342-3 p\end{array}$ & $\begin{array}{l}\mathrm{miR}- \\
425^{*}\end{array}$ & $\begin{array}{l}\text { miR- } \\
451 \#\end{array}$ & miR-551a & - & - & - & - \\
\hline & miR-622 & $\begin{array}{l}\text { miR- } \\
708\end{array}$ & $\begin{array}{c}\text { miR- } \\
106 b-25\end{array}$ & - & - & - & - & - & - & - & - & - \\
\hline & $\begin{array}{c}\text { miR-18a- } \\
5 p\end{array}$ & $\begin{array}{l}\mathrm{miR}- \\
21 \#\end{array}$ & miR-23b & miR-27b & miR-24 & miR-29b & $\begin{array}{l}\text { miR- } \\
34 a \#\end{array}$ & miR-143 & - & - & - & - \\
\hline \multirow[t]{5}{*}{ Treatment } & miR-199a & $\begin{array}{c}\text { miR- } \\
\text { 200c\# }\end{array}$ & miR-210 & miR-146a & $\begin{array}{l}\text { miR- } \\
\text { 375\# }\end{array}$ & $\begin{array}{c}\text { miR- } \\
491-5 p \#\end{array}$ & $\begin{array}{c}\text { miR-17- } \\
92\end{array}$ & - & - & - & - & - \\
\hline & let-7b & miR-1 & miR-10b & miR-15/b & miR-16 & miR-21\# & $\operatorname{miR}-23 b$ & miR-24 & $\begin{array}{c}\text { miR- } \\
15 a / 16-1\end{array}$ & miR-129 & $\begin{array}{c}\text { miR- } \\
146 b-3 p\end{array}$ & - \\
\hline & miR-30d & $\begin{array}{l}\mathrm{miR}- \\
31 \#\end{array}$ & miR-34b\# & miR-96 & miR-100 & $\begin{array}{l}\text { miR- } \\
106 b\end{array}$ & $\begin{array}{c}\text { miR- } \\
133 \mathrm{b \#}\end{array}$ & $\begin{array}{c}\text { miR- } \\
135 a / b \#\end{array}$ & miR-152 & miR-194\# & $\begin{array}{l}\text { miR- } \\
375 \#\end{array}$ & - \\
\hline & miR-143 & $\begin{array}{c}\text { miR- } \\
151-3 p\end{array}$ & $\begin{array}{c}\text { miR- } \\
\text { 182\#/- } \\
5 p \#\end{array}$ & miR-183 & miR-187 & $\begin{array}{c}\text { miR- } \\
188-5 p\end{array}$ & $\begin{array}{l}\text { miR- } \\
194 \#\end{array}$ & miR-200a & $\begin{array}{l}\text { miR- } \\
\text { 1290\# }\end{array}$ & - & - & - \\
\hline & miR-205 & $\begin{array}{c}\text { miR- } \\
210\end{array}$ & miR-221\# & miR-222\# & $\operatorname{miR}-224$ & $\begin{array}{l}\text { miR- } \\
\text { 301a\# }\end{array}$ & $\begin{array}{c}\text { miR-331- } \\
3 p\end{array}$ & miR-375\# & - & - & - & - \\
\hline \multirow[t]{4}{*}{ Prognosis } & miR-429 & $\begin{array}{l}\text { miR- } \\
\text { 449b\# }\end{array}$ & miR-452 & $\begin{array}{c}\text { miR-511- } \\
3 p\end{array}$ & $\begin{array}{c}\text { miR- } \\
516-3 p\end{array}$ & miR-708 & miR-711 & miR-940 & - & - & - & - \\
\hline & $\begin{array}{c}\text { miR- } \\
\text { 1207-3p\# }\end{array}$ & $\begin{array}{l}\text { miR- } \\
\text { 2909\# }\end{array}$ & $\begin{array}{c}\text { miR- } \\
4638-5 p\end{array}$ & $\mathrm{miQ}$ & $\begin{array}{c}\text { miR- } \\
106 b-25\end{array}$ & - & - & - & - & - & - & - \\
\hline & let-7c\# & miR-1 & miR-16 & miR-31\# & miR-32 & miR-33 & $\begin{array}{c}\text { miR- } \\
\text { 34a\#/b\# }\end{array}$ & miR-126* & miR-194 & $\begin{array}{c}\text { miR-628- } \\
5 p\end{array}$ & - & - \\
\hline & $\begin{array}{c}\text { miR-141- } \\
3 p\end{array}$ & $\begin{array}{c}\text { miR- } \\
143\end{array}$ & miR-145\# & miR-154* & $\begin{array}{l}\text { miR- } \\
181 a\end{array}$ & miR-195 & miR-205 & miR-379 & - & - & - & - \\
\hline Metastasis & $\begin{array}{c}\text { miR-409- } \\
3 p /-5 p\end{array}$ & $\begin{array}{c}\text { miR- } \\
518 f-5 p\end{array}$ & miR-573\# & $\mathrm{miQ}$ & - & - & - & - & - & - & - & - \\
\hline
\end{tabular}

Note: \#-microRNAs detected in both prostate cancer tissues and serum or microRNAs with mechanism studies were conducted; $\mathrm{miQ}=(\mathrm{miR}-96-5 \mathrm{p} \times \mathrm{miR}-183-5 \mathrm{p}) /(\mathrm{miR}-145-5 \mathrm{p} \times \mathrm{miR}-221-5 \mathrm{p})$ 
[39], miR-23a, miR-24-2, miR-27a [40], miR-19a, miR-133b [41] miR-125b [42], miR-148 [43], miR-182-5p [44], miR-126, miR181b-I, miR-181c, miR-221, miR-338 [45] and miR-421 [46], and so on, androgen responsive element (ARE) might exist in these miRNAs flanking sequences. AR could also inhibit or activate the expression of miR-99a, let-7c and miR-125b-2 by chromatin remodeling factors: EZH2 or JMJD3 [47]. In addition, let-7d [48], miR-10a, miR-141, miR-15* and miR-1225-5p [49], were regulated by androgen.

\section{MicroRNAs associated with metastatic prostate cancer and CRPC}

Metastasis and castration resistance were two characteristics of advanced PCa. EMT (epithelial to mesenchymal transition) was the important performance of metastasis, while MET (mesenchymal to epithelial transition) was the phenotype of benign reversion of $\mathrm{PCa}$. The researchers commonly used interdermal markers: fibronectin, ZEBI, ZEB2, vimentin, ZO1, snail and epithelial marker: E-cadherin, to monitor the occurrence and development of metastasis.

Osthole, a coumarin extracted from medicinal plants, inhibited EMT and metastasis by down-regulating the expression of miR$23 a-3 p$ to reduce E-cadherin expression and Snail DNA-binding ability [50]. Snail was also confirmed to be the target gene of miR486-5p [51], miR-182 and miR-203 [52]. The members of miR200 family, miR-200c and miR-141, inhibited JAGGEDI protein expression, and further regulated ZEB1 which was a mesothelial marker [22]. miR-210-3p participated in NF-kB signaling via targeting TNIP1 and SOCS1 to trigger EMT, migration and bone metastasis [53]. miR-9 was an oncomiR targeting E-cadherin [54], while miR-573 was a tumor suppressor to directly target FGFR1 gene [55].

So far, metastatic castration-resistant prostate cancer (mCRPC) is considered incurable. miRNAs may play an important role in the malignant transformation process of $\mathrm{PCa}$ to this terminal stage. There was study finding that miRNA-221/222 was up-regulated in CRPC [14]. miR-145-5p and miR-145-3p were down-regulated in CRPC, and miR-145-3p had four downstream target genes: MELK, NCAPG, BUB1, and CDK1 [56]. In addition, miR-1290 and miR-375 might be the potential prognostic biomarkers for CRPC patients in exosomes [57].

\section{Conclusion}

As a group of small non-coding RNA molecules, microRNAs, combined with long non-coding RNAs, jointly regulate complex signal networks with different mechanisms. Are they subordinate or dominant in the occurrence and development of PCa? What are the mechanisms by which they contribute to PCa? These questions are far from being answered by researchers. We still need a lot of further researches to reveal the rules, and to provide the powerful theoretical basis for early diagnosis, prognosis prediction and targeted treatment for PCa.

\section{Acknowledgement}

This work was supported by Zhejiang Provincial Science Technology Program of China (2013C33101), Zhejiang Medical Platform Program (2015RCA023), and Shaoxing municipal health and family planning science and technology innovation project (2017CX004).

\section{References}

1. Siegel RL, Miller KD, Jemal A (2017) Cancer statistics. CA Cancer J Clin 67: 7-30.

2. Wakaskar RR (2018) Brief overview of nanoparticulate therapy in cancer. J Drug Target 26: 123-126.

3. Wakaskar RR (2018) Promising effects of nanomedicine in cancer drug delivery. J Drug Target 26: 319-324.

4. Bartel DP (2004) MicroRNAs: genomics, biogenesis, mechanism, and function. Cell 116: 281-297.

5. Song C, Chen H, Wang T, Zhang W, Ru G, et al. (2015) Expression profile analysis of microRNAs in prostate cancer by next-generation sequencing. Prostate 75: 500-516.

6. Coppola V, De Maria R, Bonci D (2010) MicroRNAs and prostate cancer. Endocr Relat Cancer 17: 1-17.

7. Kanwal R, Plaga AR, Liu X, Shukla GC, Gupta S, et al. (2017) MicroRNAs in prostate cancer: Functional role as biomarkers. Cancer Lett 407: 9-20.

8. Song CJ, Chen H, Chen LZ, Ru GM, Guo JJ, et al. (2018) The potential of microRNAs as human prostate cancer biomarkers: A meta-analysis of related studies. J Cell Biochem 119: 27632786.

9. Larne O, Martens-Uzunova E, Hagman Z, Edsjo A, Lippolis $G$, et al. (2013) miQ-a novel microRNA based diagnostic and prognostic tool for prostate cancer. Int J Cancer 132: 2867 2875.

10. Qin W, Shi Y, Zhao B, Yao C, Jin L, et al. (2010) miR-24 regulates apoptosis by targeting the open reading frame (ORF) region of FAF1 in cancer cells. PLoS One 5: e9429.

11. Liu C, Tang DG (2011) MicroRNA regulation of cancer stem cells. Cancer Res 71: 5950-5954.

12. Majid S, Dar AA, Saini S, Yamamura S, Hirata H, et al. (2010) MicroRNA-205-directed transcriptional activation of tumor suppressor genes in prostate cancer. Cancer 116: 5637-5649.

13. Chiosea S, Jelezcova E, Chandran U, Acquafondata M, McHale $T$, et al. (2006) Up-regulation of dicer, a component of the MicroRNA machinery, in prostate adenocarcinoma. Am J Pathol 169: 1812-1820.

14. Sun T, Du SY, Armenia J, Qu F, Fan J, et al. (2018) Expression of IncRNA MIR222HG co-transcribed from the miR-221/222 
gene promoter facilitates the development of castrationresistant prostate cancer. Oncogenesis 7: p30.

15. Terzuoli E, Donnini S, Finetti F, Nesi G, Villari D, et al. (2016 ) Linking microsomal prostaglandin E Synthase-1/PGE-2 pathway with miR-15a and -186 expression: Novel mechanism of VEGF modulation in prostate cancer. Oncotarget 7: 4435044364.

16. Wei LZ, Wang YQ, Chang YL, An N, Wang X, et al. (2018) Imbalance of a KLF4-miR-7 auto-regulatory feedback loop promotes prostate cancer cell growth by impairing microRNA processing. Am J Cancer Res 8: 226-244.

17. Koh CM, Iwata T, Zheng Q, Bethel C, Yegnasubramanian S, et al. (2011) Myc enforces overexpression of EZH2 in early prostatic neoplasia via transcriptional and post-transcriptional mechanisms. Oncotarget 2: 669-683.

18. Shiina $M$, Hashimoto $Y$, Kato T, Yamamura $S$, Tanaka $Y$, et al. (2017) Differential expression of miR-34b and androgen receptor pathway regulate prostate cancer aggressiveness between African-Americans and Caucasians. Oncotarget 8: 8356-8368.

19. Calin GA, Sevignani C, Dumitru CD, Hyslop T, Noch E, et al. (2004) Human microRNA genes are frequently located at fragile sites and genomic regions involved in cancers. Proc Natl Acad Sci USA 101: 2999- 3004.

20. Damodaran M, Paul SFD, Venkatesan V (2018) Genetic polymorphisms in miR-146a, miR-196a2 and miR-125a Genes and its association in prostate cancer. Pathol Oncol Res

21. Narouie B, Ziaee SAM, Basiri A, Hashemi M (2017) Functional polymorphism at the miR-502-binding site in the $3^{\prime}$ untranslated region of the SETD8 gene increased the risk of prostate cancer in a sample of Iranian population. Gene 626: 354-357.

22. Abisoye-Ogunniyan $A$, Lin $H$, Ghebremedhin $A$, Salam $A B$, Karanam B, et al. (2018) Transcriptional repressor kaiso promotes epithelial to mesenchymal transition and metastasis in prostate cancer through direct regulation of miR-200c. Cancer Lett 431: 1-10.

23. Fort RS, Mathó C, Oliveira-Rizzo C, Garat B, Sotelo-Silveira JR, et al. (2018) An integrated view of the role of miR-130b/301b miRNA cluster in prostate cancer. Exp Hematol Oncol 7: 10.

24. Ramalho-Carvalho J, Gonçalves CS, Graça I, Bidarra D, PereiraSilva $E$, et al. (2018) A multiplatform approach identifies miR152-3p as a common epigenetically regulated onco-suppressor in prostate cancer targeting TMEM97. Clin Epigenetics 10: 40.

25. Sun R, Fu X, Li Y, Xie Y, Mao Y, et al. (2009) Global gene expression analysis reveals reduced abundance of putative microRNA targets in human prostate tumours. BMC Genomics 10: 93.

26. Feng N, Xu B, Tao J, Li P, Cheng G, et al. (2012) A miR-125b binding site polymorphism in bone morphogenetic protein membrane receptor type IB gene and prostate cancer risk in China. Mol Biol Rep 39: 369-73.

27. ChunJiao S, Huan C, ChaoYang X, GuoMei R. (2014) Uncovering the roles of miRNAs and their relationship with androgen receptor in prostate cancer. IUBMB Life 66: 379-386.

28. Östling P, Leivonen SK, Aakula A, Kohonen P, Mäkelä R, et al. (2011) Systematic analysis of microRNAs targeting the androgen receptor in prostate cancer cells. Cancer Res 71: 1956-1967.

29. Shi XB, Ma AH, Xue L, Li M, Nguyen HG, et al. (2015) miR-124 and androgen receptor signaling inhibitors repress prostate cancer growth by downregulating androgen receptor splice variants, ezh2, and src. Cancer Res 75: 5309-5317.

30. Larne O, Hagman Z, Lilja H, Bjartell A, Edsjö A, et al. (2015) miR-145 suppress the androgen receptor in prostate cancer cells and correlates to prostate cancer prognosis. Carcinogenesis36: 858-866.

31. Xie H, Li L, Zhu G, Dang Q, Ma Z, et al. (2015) Infiltrated pre-adipocytes increase prostate cancer metastasis via modulation of the miR-301a/androgen receptor (AR)/TGF- $\beta 1$ / Smad/MMP9 signals. Oncotarget 6: 12326-12339.

32. Sato S, Katsushima K, Shinjo K, Hatanaka A, Ohka F, et al. (2016 ) Histone deacetylase inhibition in prostate cancer triggers mir-320-mediated suppression of the androgen receptor. Cancer Res 76: 4192-4204.

33. Zheng L, Chen J, Ma Z, Liu W, Yang F, et al. (2015) Capsaicin causes inactivation and degradation of the androgen receptor by inducing the restoration of miR-449a in prostate cancer. Oncol Rep 34: 1027-1034.

34. Anis $Y$, Leshem O, Reuveni H, Wexler I, Ben Sasson R, et al. (2004) Antidiabetic effect of novel modulating peptides of G-protein-coupled kinase in experimental models of diabetes. Diabetologia 47: 1232-1244.

35. Das DK, Naidoo M, Ilboudo A, Park JY, Ali T, et al. (2016) miR1207-3p regulates the androgen receptor in prostate cancer 
via FNDC1/fibronectin. Exp Cell Res 348: 190-200.

36. Jiang CY, Ruan Y, Wang XH, Zhao W, Jiang Q, et al. (2016) MiR185 attenuates androgen receptor function in prostate cancer indirectly by targeting bromodomain containing 8 isoform 2, an androgen receptor co-activator. Mol Cell Endocrinol 427: 13-20.

37. Ayub SG, Kaul D, Ayub T (2017) An androgen-regulated miR2909 modulates TGF $\beta$ signalling through AR/miR-2909 axis in prostate cancer. Gene 631: 1-9.

38. Chu M, Chang Y, Guo Y, Wang N, Cui J, et al. (2015) Regulation and methylation of tumor suppressor miR-124 by androgen receptor in prostate cancer cells. PLoS One10: e0116197.

39. Mishra S, Deng JJ, Gowda PS, Rao MK, Lin CL, et al. (2014) Androgen receptor and microRNA-21 axis downregulates transforming growth factor beta receptor II (TGFBR2) expression in prostate cancer. Oncogene. 33: 4097-4106.

40. Fletcher CE, Dart DA, Sita-Lumsden A, Cheng H, Rennie PS, et al. (2012) Androgen-regulated processing of the oncomir miR-27a, which targets prohibitin in prostate cancer. Hum Mol Genet 21: 3112-3127.

41. Mo W, Zhang J, Li X, Meng D, Gao Y, et al. (2013) Identification of novel AR-targeted microRNAs mediating androgen signalling through critical pathways to regulate cell viability in prostate cancer. PLoS One 8: e56592.

42. DeVere White RW, Vinall RL, Tepper CG, Shi XB (2009) MicroRNAs and their potential for translation in prostate cancer. Urol Oncol 27: 307-311.

43. Huang YL, Bach SM (2016) Appointment lead time policy development to improve patient access to care. Appl Clin Inform 7: 954-968.

44. Yao J, Xu C, Fang Z, Li Y, Liu H, et al. (2016) Androgen receptor regulated microRNA miR-182-5p promotes prostate cancer progression by targeting the ARRDC3/ITGB4 pathway. Biochem Biophys Res Commun 474: 213-219.

45. Ambs S, Prueitt RL, Yi M, Hudson RS, Howe TM, et al. (2008) Genomic profiling of microRNA and messenger RNA reveals deregulated microRNA expression in prostate cancer. Cancer Res 68: 6162-6170.

46. Meng D, Yang S, Wan X, Zhang Y, Huang W, et al. (2016) A transcriptional target of androgen receptor, miR-421 regulates proliferation and metabolism of prostate cancer cells. Int J Biochem Cell Biol 73: 30-40.
47. Sun D, Layer R, Mueller AC, Cichewicz MA, Negishi M, et al. (2014) Regulation of several androgen-induced genes through the repression of the miR-99a/let-7c/miR-125b-2 miRNA cluster in prostate cancer cells. Oncogene 33: 1448-1457.

48. Ramberg H, Alshbib A, Berge V, Svindland A, Taskén KA (2011) Regulation of PBX3 expression by androgen and Let-7d in prostate cancer. Mol Cancer 10: 50.

49. Waltering KK, Porkka KP, Jalava SE, Urbanucci A, Kohonen PJ, et al. (2011) Androgen regulation of micro-RNAs in prostate cancer. Prostate 71: 604-614.

50. Wen YC, Lee WJ, Tan P, Yang SF, Hsiao M, et al. (2015) By inhibiting snail signaling and miR-23a-3p, osthole suppresses the EMT-mediated metastatic ability in prostate cancer. Oncotarget 6: 21120-21136.

51. Zhang X, Zhang T, Yang K, Zhang M, Wang K, et al. (2016) miR486-5p suppresses prostate cancer metastasis by targeting Snail and regulating epithelial-mesenchymal transition. Onco Targets Ther 9: 6909-6914.

52. Qu Y, Li WC, Hellem MR, Rostad K, Popa M, et al. (2013) MiR182 and miR-203 induce mesenchymal to epithelial transition and self-sufficiency of growth signals via repressing SNAI2 in prostate cells. Int J Cancer 133: 544-555.

53. Ren D, Yang Q, Dai Y, Guo W, Du H, et al. (2017) Oncogenic miR-210-3p promotes prostate cancer cell EMT and bone metastasis via NF-KB signaling pathway. Mo Cancer 16: 117.

54. Seashols-Williams SJ, Budd W, Clark GC, Wu Q, Daniel R, et al. (2016) miR-9 acts as an oncomir in prostate cancer through multiple pathways that drive tumour progression and metastasis. PLos One 11: e0159601.

55. Wang L, Song G, Tan W, Qi M, Zhang L, et al. (2015) MiR-573 inhibits prostate cancer metastasis by regulating epithelialmesenchymal transition. Oncotarget 6: 35978-35990.

56. Goto Y, Kurozumi A, Arai T, Nohata N, Kojima S, et al. (2017) Impact of novel miR-145-3p regulatory networks on survival in patients with castration-resistant prostate cancer. $\mathrm{Br} \mathrm{J}$ Cancer 117: 409-420.

57. Huang X, Yuan T, Liang M, Du M, Xia S, et al. (2015) Exosomal miR-1290 and miR-375 as prognostic markers in castrationresistant prostate cancer. Eur Urol 67: 33-41. 